\title{
The Exigencies of Environmental Protection Against the Vulnerabilities of Natural Disasters
}

\author{
Mirela Mazilu ${ }^{1, a^{*}}$ and Stefan Ispas ${ }^{2, b}$ \\ ${ }^{1}$ University of Craiova, Department of Geography, Romania \\ ${ }^{2}$ University Valahia of Targoviste, Department of Geography, Romania \\ amirelamazilu2004@yahoo.com, bstispas@yahoo.com
}

Keywords: disaster, efficiency, tourism, effects, erosion

\begin{abstract}
Motto: "We cannot prevent disasters ... What we hope to do is to be more proactive, to be better prepared so that we can react better, faster." Winston Choo, 2006

The exigencies of environmental protection must be concomitantly achieved both at micro and macroeconomic levels, at individual and national states and international communities' levels. No matter the scale we refer to, there should be taken strict actions meant to modify the present tendencies of environmental deterioration in order to permanently maintain an equitable balance between satisfying the more and more diverse necessities of present society and protecting all components of environment. Although it is difficult or, in some cases, even impossible to establish their appearance within time and space coordinates, the majority associates them with the period of industrial revolution, because the man's wish of a better, more sustainable life has uncontrollable effects on the environment, or the climate. Thus, the change with its multiple faces and components remains a priority for the protection of the environment and of the sustainable development, and people face the most important choice of their long history.

One with paradigmatic values - having rational, ecologic, protectionist, emotional, educational valences - generated by the troubling metamorphoses like: the exhaustion of natural resources, "baby-boom" beyond any control, the ecologic unbalances, the inequality of chances when education, health and carrier are concerned.
\end{abstract}

\section{Introduction}

The human society survives nowadays in a natural and anthropogenic environment in a continuous change, being exposed to a wide variety of more or less dangerous situations, generated by numerous factors, of natural as well as anthropogenic origin. The frequent manifestations of extreme natural phenomena, such as powerful earthquakes, droughts, heavy rains, floods, landslides, storms and strong hurricanes, to which we can add the multiple technogenic accidents and the various social conflicts, can have a direct influence on the health and the welfare of each person, as well as on the society as a whole. The statistics shows that $95 \%$ of all the human victims caused by the natural hazards belongs to the countries in development. In the rich countries, the number of these victims is very small, but the economic prejudice reaches $75 \%$ of the global material losses. All these and many other risk natural phenomena from the last decades have conditioned the need to intensify the activities intended to prevent and mitigate the consequences of natural hazards, nationally and internationally, for the international cooperation in the field.

This necessity was mentioned in a series of international documents and, especially, in the Millennium Declaration (Resolution 55/2 of the UNO General Meeting, New York, 2000), stating the fundamental principles and values of sustainable development of the human society in the XXI century. This document mainly specifies "...the need to make common endeavours to prevent and reduce the effects of natural disasters, as well as of the ones caused by people". This provision may be qualified as one of the millennial purposes, which must be achieved by the international community until 2015. Considering the essence of the statement in this matter, we can specify that the centre of gravity of these field activities is set not on the removal of the consequences of the hazards, meaning on activities intended to remedy or recover after the situations caused by these 
disasters, but on activities to prevent them. The practice of the last centuries has already proved that it is much more efficient to invest in the prevention of hazards than to remove their consequences. Considering the increasing proportions of the consequences of the natural disasters, this issue is more and more frequent in the agenda of many international development agencies and of the ones offering assistance for the underdeveloped countries or for the ones in development. If these institutions were more concerned with the "reactions" to these phenomena already occurred in the previous stage, then, over the last two decades, they have been focused more on the actions that are connected to the preparation to face these phenomena, to mitigate and prevent their impact, including on the field training of the employees.

According to the annual reports of the Red Cross International Federation (RCIF), the number of natural hazards in the world grew with 70\% during the period 2004-2006, and, in 2007, this number increased with approximately $20 \%$ more and reached over 500, the climate global warming consequences being a reason for this tendency. Therefore, during the last decade (1997-2006), the number of natural hazards grew with $60 \%$ compared with the previous decade (1987-1996). In the present, the losses following the hazards obviously grow and are accompanied by serious consequences from the point of view of the survival, of the welfare and of the means of existence of the people, especially of the poorest class of the population, and of the loss of the goods gained with hard work during the process of development. In the world, the annual material losses grew ten times following the hazards during the last 50 years (Table 1).

Tabel 1 Annual Disaster Statistical Review 2012 - The numbers and trends [1]

\begin{tabular}{|l|r|r|r|r|r|r|}
\hline Damages (2012 Us\$ bn) & \multicolumn{1}{|c|}{ Africa } & Americas & \multicolumn{1}{|c|}{ Asia } & Europe & Oceania & \multicolumn{1}{c|}{ Global } \\
\hline Climatological 2012 & 0.00 & 22.46 & 0.02 & 4.15 & 0.00 & 26.63 \\
\cline { 2 - 7 } Avg. 2002-11 & 0.04 & 2.79 & 3.50 & 2.76 & 0.39 & 9.49 \\
\hline Geophysical 2012 & 0.00 & 0.68 & 2.14 & 15.80 & 0.00 & 18.62 \\
\cline { 2 - 7 } Avg. 2002-11 & 0.57 & 4.08 & 36.73 & 0.53 & 2.47 & 44.36 \\
\hline Hydrological 2012 & 0.83 & 0.58 & 19.25 & 4.24 & 0.70 & 25.61 \\
\cline { 2 - 7 } Avg. 2002-11 & 0.31 & 3.95 & 13.51 & 4.73 & 1.16 & 23.66 \\
\hline Meteorological 2012 & 0.10 & 79.67 & 6.56 & 0.01 & 0.15 & 86.48 \\
\cline { 2 - 7 } Avg. 2002-11 & 0.07 & 39.14 & 8.19 & 3.64 & 0.77 & $\mathbf{5 1 . 8 1}$ \\
\hline Total 2012 & $\mathbf{0 . 9 3}$ & 103.38 & $\mathbf{2 7 . 9 7}$ & $\mathbf{2 4 . 2 0}$ & $\mathbf{0 . 8 5}$ & $\mathbf{1 5 7 . 3 4}$ \\
\cline { 2 - 7 } Avg. 2002-11 & $\mathbf{0 . 9 9}$ & $\mathbf{4 9 . 9 6}$ & $\mathbf{6 1 . 9 3}$ & $\mathbf{1 1 . 6 6}$ & $\mathbf{4 . 7 8}$ & $\mathbf{1 2 9 . 3 3}$ \\
\hline
\end{tabular}


Table 2 Natural disaster subgroup definition and classification [2]

\begin{tabular}{|c|c|c|}
\hline GEOPHYSICAL & $\begin{array}{l}\text { Events originating } \\
\text { from solid earth }\end{array}$ & $\begin{array}{l}\text { Earthquake, Volcano, } \\
\text { Mass Movement (dry) }\end{array}$ \\
\hline METEOROLOGICAL & $\begin{array}{c}\text { Events caused by short- } \\
\text { lived/small to meso scale } \\
\text { atmospheric processes (in the } \\
\text { spectrum from } \\
\text { minutes to days } \\
\text { Events caused by deviations in } \\
\text { the normal water cycle and/or } \\
\text { overflow of bodies of water caused } \\
\text { by wind set-up }\end{array}$ & $\begin{array}{r}\text { Flood, Mass } \\
\text { Movement (wet) }\end{array}$ \\
\hline CLIMATOLOGICAL & $\begin{array}{l}\text { Events caused by long- } \\
\text { lived/meso to macro scale } \\
\text { processes (in the spectrum from } \\
\text { intra-seasonal to multi-decadal } \\
\text { climate variability) }\end{array}$ & $\begin{array}{l}\text { Extreme Temperature, } \\
\text { Drought, Wildfire }\end{array}$ \\
\hline $\begin{array}{l}\text { BIOLOGICAL* } \\
* * * \text { Biological disasters } \\
\text { are not included in this } \\
\text { publication }\end{array}$ & $\begin{array}{l}\text { Disaster caused by the } \\
\text { exposure of living organisms to } \\
\text { germs and toxic substances }\end{array}$ & $\begin{array}{l}\text { Epidemic, Insect } \\
\text { Infestation, Animal } \\
\text { Stampede }\end{array}$ \\
\hline
\end{tabular}

Looking at the geographical distribution of disasters, Asia was the continent most often hit by natural disasters in 2012 (40.7\%), followed by the Americas (22.2\%), Europe (18.3\%), Africa $(15.7 \%)$, and Oceania (3.1\%). This regional distribution of disaster occurrence resembles the profile observed from 2002 to 2011. In 2012, disaster occurrence in Europe was more than three times the one for 2011 and surpassed its 2002-2012 annual average. Inversely, in Africa, the Americas, Asia and Oceania, disaster occurrences were below the decade annual average.

The estimated economic losses from natural disasters in 2012 (US\$ 157 billion) surpassed of almost $10 \%$ the annual average damages from 2001 to 2010 (US\$ 143 billion). Hurricane Sandy (US\$ 50 billion) was the second costliest storm of the decade, but far behind Hurricane Katrina (2012 US\$ 147 billion). Damages from the drought in the South-Western and Mid-West regions of the United States (US\$ 20 billion) were the highest reported for the decade. These two disasters accounted for $45 \%$ of the total amount of reported damages [3].

The DIPECHO programme had been expanded over the years and now covers eight disaster prone regions: the Caribbean, Central America, South America, Central Asia (which now also includes the South Caucasus countries), South Asia, South East Asia, South East Africa and South West Indian Ocean and Pacific Region (see map - fig.1). 


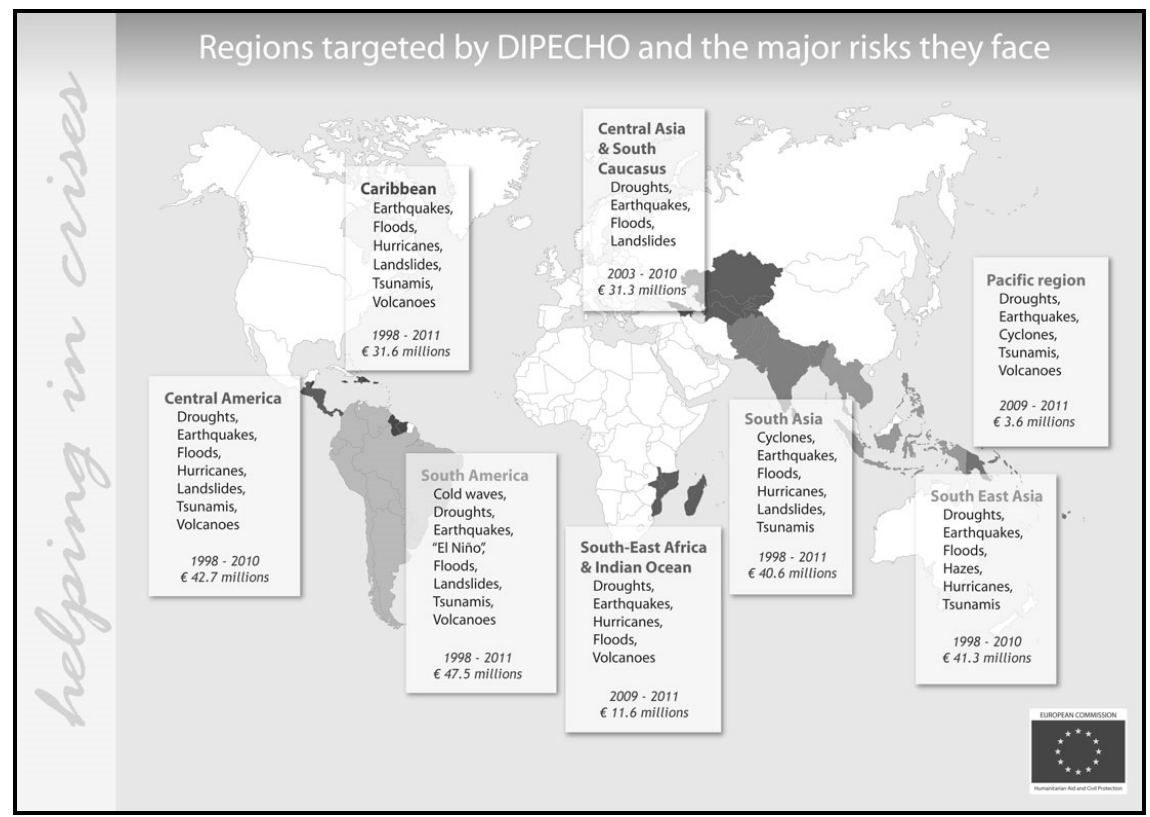

Fig.1 Contribution to international Disaster Risk Reduction efforts (Source: the Hyogo Framework for Action 2005-2015)

ECHO strongly supports all international efforts, including those coordinated by the United Nations, to increase disaster risk reduction worldwide.

ECHO therefore actively supported the World Conference for Disaster Reduction held in Kobe, Japan in January 2005 following the Tsunami. This conference was one of the milestone events that led to the formulation of the Hyogo Framework for Action 2005-2015 and the international commitment to strengthen the International System for Disaster Reduction (ISDR) established within the auspices of UN OCHA. During the different sessions of the Global Platform for Disaster Risk Reduction, held in 2007, 2009 and 2011, ECHO actively participated sharing its strategy and experience in community based Preparedness and Disaster Risk Reduction with government representatives, specialized UN agencies, lead donors, the Red Cross and Red Crescent movement, scientific and regional experts, civil society and private sector representatives. The number of reported disasters in Europe (65) was above the annual average disaster occurrence from 2002 to 2012 (56). This is largely due to cold waves and extreme winter conditions which affected most European countries in the beginning of the year. The number of such climatologically disasters (45) is almost three times superior to its annual average for years 2002-2011 (17). Inversely, 2012 shows a strong decrease in the number of hydrological disasters (16), compared to an annual average of 23. Such decrease is still more pronounced for meteorological disasters: only one was reported in 2012 - the lowest number ever reported since years 1990 - compared to an annual average of 14 in years 2002-2011. Therefore, compared to the previous decade, 2012 appears, in Europe, as an atypical year, with disasters occurring in proportions distinctly different from those of previous years.

In 2012, the decrease in the number of victims (0.58 million) compared to their 2002-2011 annual average ( 0.66 million) is largely explained by the decrease of their number in meteorological disasters (-99.7\% in 2012 compared to the 2002-2011 annual average) and in hydrological disasters $(-62.2 \%)$. In contrast, compared to annual average of the years 2002-2011, the number of victims of geophysical disasters increased of $76.6 \%$ and of climatologically disasters of $68.2 \%$. Two earthquakes in Emilia-Romagna and in the Ferrare region made 14,367 and 11,057 victims, respectively. Extreme winter conditions made 230,005 victims in Albania and 18,243 in Serbia. Cold waves made 87,612 victims in Ukraine, 70,010 in Serbia and 10,351 in Bosnia-Herzegovinian. These five climatologically disasters account for $71.7 \%$ of the total of victims of disasters in Europe (Table 3). 
Table 3 Repartition of the natural disasters

\begin{tabular}{|l|r|r|r|r|r|r|}
\hline No. of natural disasters & \multicolumn{1}{|c|}{ Africa } & Americas & Asia & Europe & Oceania & Global \\
\hline Climatological 2012 & 16 & 12 & 12 & 45 & 0 & $\mathbf{8 5}$ \\
\cline { 2 - 7 } Avg. 2002-11 & 14 & 14 & 12 & 17 & 1 & $\mathbf{5 9}$ \\
\hline Geophysical 2012 & 0 & 6 & 23 & 3 & 0 & $\mathbf{3 2}$ \\
Avg. 2002-11 & 3 & 7 & 22 & 2 & 2 & $\mathbf{3 6}$ \\
\hline Hydrological 2012 & 30 & 26 & 71 & 16 & 7 & 150 \\
\cline { 2 - 7 } Avg. 2002-11 & 46 & 41 & 82 & 23 & 5 & 197 \\
\hline Meteorological 2012 & 11 & 35 & 39 & 1 & 4 & 90 \\
\cline { 2 - 7 } Avg. 2002-11 & 9 & 34 & 39 & 14 & 7 & 102 \\
\hline Total 2012 & $\mathbf{5 7}$ & $\mathbf{7 9}$ & $\mathbf{1 4 5}$ & 65 & $\mathbf{1 1}$ & $\mathbf{3 5 7}$ \\
\cline { 2 - 7 } Avg. 2002-11 & $\mathbf{7 2}$ & $\mathbf{9 5}$ & $\mathbf{1 5 6}$ & $\mathbf{5 6}$ & $\mathbf{1 6}$ & $\mathbf{3 9 4}$ \\
\hline
\end{tabular}

Table 4 The Number of victims produced by disasters

\begin{tabular}{|l|r|r|r|r|r|r|}
\hline No. of victims (millions) & Africa & Americas & \multicolumn{1}{|c|}{ Asia } & Europe & Oceania & \multicolumn{1}{|c|}{ Global } \\
\hline Climatological 2012 & 28.01 & 1.82 & 6.37 & 0.45 & 0.00 & $\mathbf{3 6 . 6 5}$ \\
\cline { 2 - 7 } Avg. 2002-11 & 23.86 & 1.36 & 76.80 & 0.27 & 0.00 & $\mathbf{1 0 2 . 2 9}$ \\
\hline Geophysical 2012 & 0.00 & 1.41 & 1.48 & 0.03 & 0.00 & $\mathbf{2 . 9 1}$ \\
\cline { 2 - 7 } Avg. 2002-11 & 0.08 & 0.83 & 7.13 & 0.01 & 0.07 & $\mathbf{8 . 1 2}$ \\
\hline Hydrological 2012 & 9.34 & 1.54 & 53.52 & 0.10 & 0.24 & $\mathbf{6 4 . 7 4}$ \\
\cline { 2 - 7 } Avg. 2002-11 & 2.08 & 4.26 & 111.05 & 0.28 & 0.06 & $\mathbf{1 1 7 . 7 1}$ \\
\hline Meteorological 2012 & 0.47 & 0.80 & 18.93 & 0.00 & 0.02 & $\mathbf{2 0 . 2 2}$ \\
\cline { 2 - 7 } Avg. 2002-11 & 0.37 & 2.19 & 37.05 & 0.11 & 0.04 & $\mathbf{3 9 . 7 5}$ \\
\hline Total 2012 & $\mathbf{3 7 . 8 2}$ & $\mathbf{5 . 5 7}$ & $\mathbf{8 0 . 2 9}$ & $\mathbf{0 . 5 8}$ & $\mathbf{0 . 2 6}$ & $\mathbf{1 2 4 . 5 2}$ \\
\cline { 2 - 7 } Avg. 2002-11 & $\mathbf{2 6 . 3 8}$ & $\mathbf{8 . 6 4}$ & $\mathbf{2 3 2 . 0 3}$ & $\mathbf{0 . 6 6}$ & $\mathbf{0 . 1 7}$ & $\mathbf{2 6 7 . 8 8}$ \\
\hline
\end{tabular}

Table 5 Damages produced by natural disasters

\begin{tabular}{|l|r|r|r|r|r|r|}
\hline Damages (2012 US\$ bn) & \multicolumn{1}{|c|}{ Africa } & Americas & \multicolumn{1}{|c|}{ Asia } & Europe & Oceania & \multicolumn{1}{c|}{ Global } \\
\cline { 2 - 7 } Climatological 2012 & 0.00 & 22.46 & 0.02 & 4.15 & 0.00 & $\mathbf{2 6 . 6 3}$ \\
\hline Avg. 2002-11 & 0.04 & 2.79 & 3.50 & 2.76 & 0.39 & $\mathbf{9 . 4 9}$ \\
\hline Geophysical 2012 & 0.00 & 0.68 & 2.14 & 15.80 & 0.00 & $\mathbf{1 8 . 6 2}$ \\
\cline { 2 - 7 } Avg. 2002-11 & 0.57 & 4.08 & 36.73 & 0.53 & 2.47 & $\mathbf{4 4 . 3 6}$ \\
\hline Hydrological 2012 & 0.83 & 0.58 & 19.25 & 4.24 & 0.70 & $\mathbf{2 5 . 6 1}$ \\
\cline { 2 - 7 } Avg. 2002-11 & 0.31 & 3.95 & 13.51 & 4.73 & 1.16 & $\mathbf{2 3 . 6 6}$ \\
\hline Meteorological 2012 & 0.10 & 79.67 & 6.56 & 0.01 & 0.15 & $\mathbf{8 6 . 4 8}$ \\
\cline { 2 - 7 } Avg. 2002-11 & 0.07 & 39.14 & 8.19 & 3.64 & 0.77 & $\mathbf{5 1 . 8 1}$ \\
\hline Total 2012 & $\mathbf{0 . 9 3}$ & $\mathbf{1 0 3 . 3 8}$ & $\mathbf{2 7 . 9 7}$ & $\mathbf{2 4 . 2 0}$ & $\mathbf{0 . 8 5}$ & $\mathbf{1 5 7 . 3 4}$ \\
\cline { 2 - 7 } Avg. 2002-11 & $\mathbf{0 . 9 9}$ & $\mathbf{4 9 . 9 6}$ & $\mathbf{6 1 . 9 3}$ & $\mathbf{1 1 . 6 6}$ & $\mathbf{4 . 7 8}$ & $\mathbf{1 2 9 . 3 3}$ \\
\hline
\end{tabular}

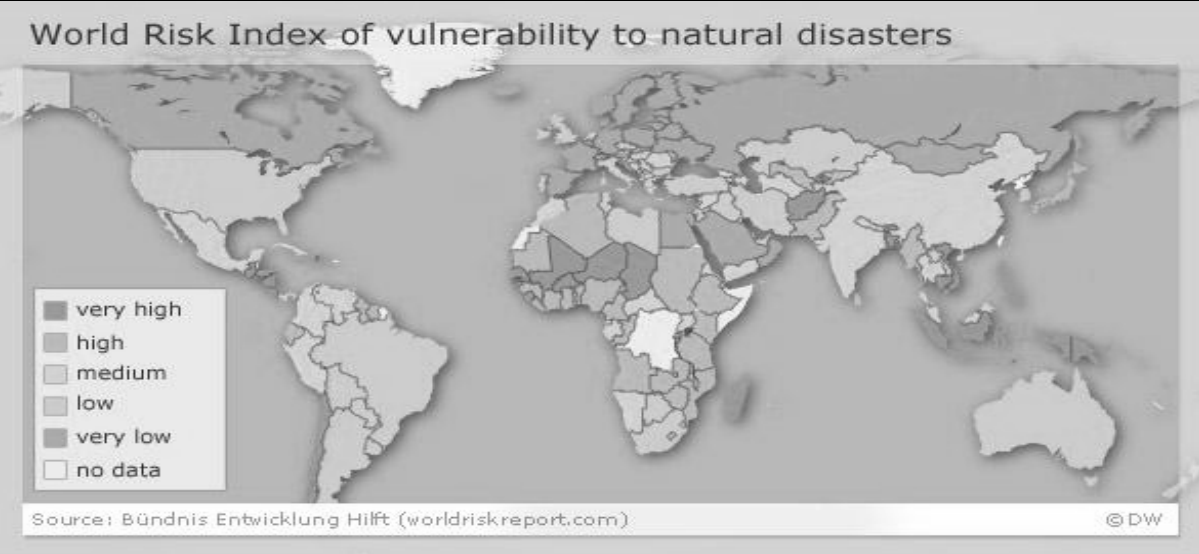

Fig.2 World risk index of vulnerability to natural disasters 
In Romania, one of the maximum vulnerability areas to the natural disasters is the area of the Black Sea coast, with large effects on the seaside tourism, holding the first place in the hierarchy of the first three tourist attractiveness areas for Romania in 2014 as well, given the following existing geographical case studies:

- The Romanian coast of the Black Sea is characterised through a much accentuated dynamic and vulnerability, which has a close connection to the extreme hydrometeorological phenomena, as well as with the anthropogenic interventions achieved on a local level or in the Danube reception basin.

- Based on the correlated action of the natural and the anthropogenic factors, the Romanian seaside of the Black Sea is affected by the erosion processes on approximately $60 \%$ of its length. Because of the lack of urgent and major works, the erosion tends to generalise, affecting the majority of the tourist resorts.

- The northern sector is characterised through an alternation of erosion processes with accumulation processes. The erosion is very pronounced, being favoured by the more active subsidence than in the southern sector, the low altitude of the relief, the lithology of deposits, as well as by the lack of river sand deposits, making the territorial losses even more significant than in the southern sector. As a consequence, the northern sector of the Romanian seaside of the Black Sea can be included in the category of risk coasts compared to the effect on a long term of the marine erosion, especially in the area of the lagoon coast of the Delta.

- The southern sector is characterised by the predominance of the erosion processes. We should mention that, in this sector, the marine erosion is associated to the landslide and collapsing processes of the sea front, especially during the humid periods or during the storms when the waves attack directly the basis of the sea front.

The works achieved, especially in the southern sector, have contributed to the end of the degradation of the beaches, but only locally, while these wide sectors continue to be affected by the erosive action of the sea. The most affected places are the beaches from the following resorts: Mamaia, Eforie Nord, Eforie Sud and Mangalia. For example, next to Constanţa, the sea front, although continuously consolidated to protect the constructions from its upper part, has withdrawn with almost $5 \mathrm{~m}$ during the last 25 years. Despite all the protection works, the sea front can withdraw at any moment through the landslide processes, generated by the accentuated slope and by the over-dampening of the deposits with the water coming from the precipitations, from the infiltrations coming from the wastewater sewerage or because of the springs emerging at the basis.

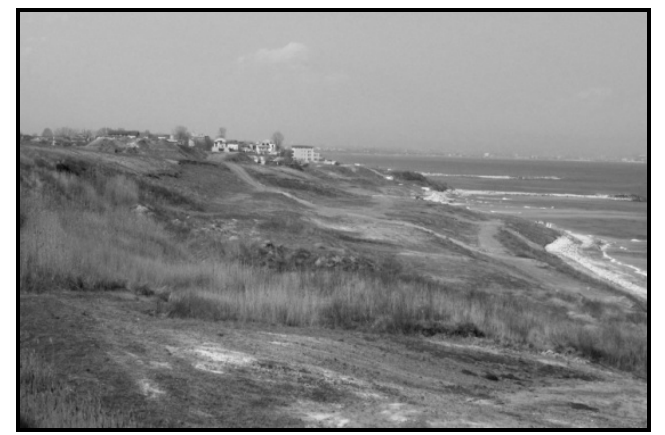

Fig. 3 The sea front affected by landslides in the South of Tuzla

- Without a general protection plan of the coast area, the beaches shall continue to degrade and reduce their surface, and the local economy shall be strongly prejudiced because of the losses recorded in tourism. Moreover, through the sea front withdrawal, numerous constructions found on their upper part are in danger of collapsing. 


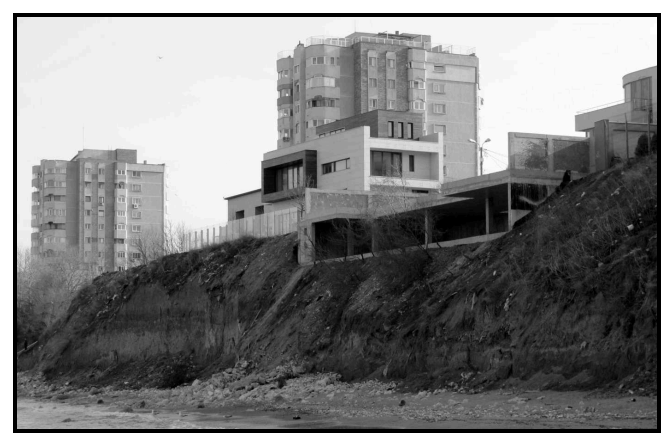

Fig.4 The sea front withdrawal next to Constanţa

- At the moment, the Dobrogea Seaside Water Directorate (DADL), the management unit responsible with the seaside protection, coordinates the execution of works to stop the marine erosion in several points of the seaside (Eforie Nord, Eforie Sud, Tuzla).

The expenses needed to stop the erosion on the entire seaside reach the amount of EUR 316 million, to which we can add other expenses for the feasibility studies, the designs and other unpredicted works (JICA, 2007).
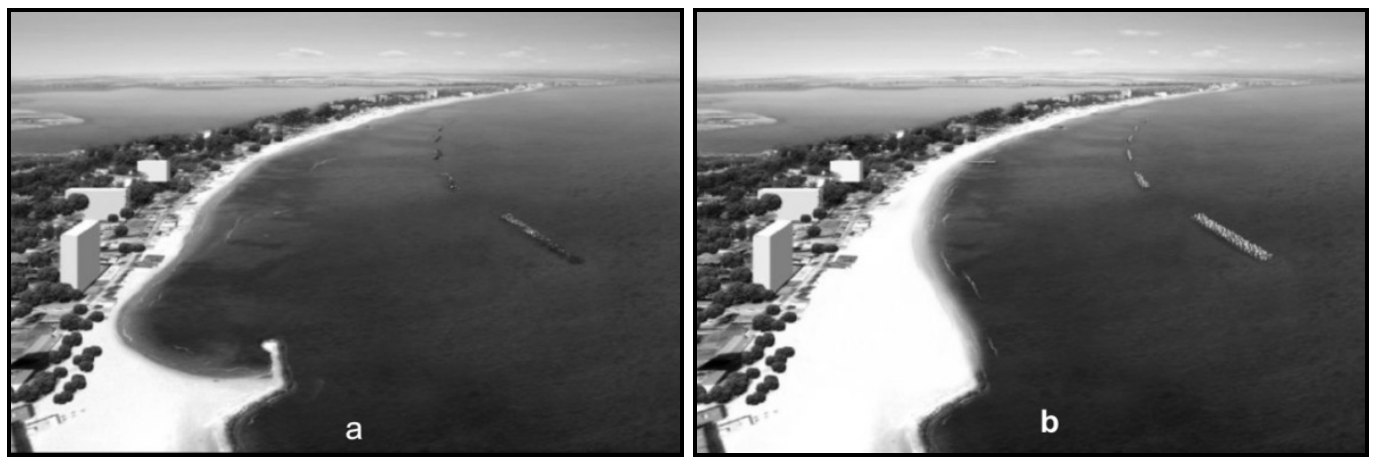

Fig.5 The beach from the South of Mamaia resort at the moment (a) and after the implementation of the JICA project (b)

In 2013, the coast area of the Romanian seaside benefited from investments of RON 27.33 million consisting of rehabilitation works of the coast area and the protection of the marine biodiversity, of which almost RON 23 million are European funds accessed through Axis 5 of the Sectorial Operational Program. Another program meant to reduce the natural disasters in the area, during the period 2014-2020, is the Romania - Bulgaria cross-border program. All the areas from the Romanian - Bulgarian cross-border region have a reduced capacity to adapt to the climatic changes (among the most reduced ones from the Eastern and Southern Europe). This indicator is influenced by five factors, such as technology, infrastructure, institutions, economic resources, know-how and the awareness and the geographic location (ESPON, 2013). The hazards and the risks may be prevented, identified and managed through: the consolidation of the capacity, which is generally low, of the region to adapt to climatic changes (through infrastructure, equipment, rules, administrative capacity, cross-border cooperation for the management of natural disasters), the continuous implementation of the projects developed before the program period (such as the measures to prevent the floods and the localisation of hazards, the development of the management system of risks, as well as a common cross-border protection system). A recent evaluation of the tourist sites along the cross-border territory shows a variety of 423 tourist sites in both countries. Two of the nine Bulgarian sites of the world, included in the cultural and natural heritage, protected by UNESCO, are located in the cross-border region - the Stone Monastery from Ivanovo and the Srebarna Natural Reservation. The tourism, one of the most powerful advantages of the region from the labour force occupation point of view and of the services turnover, is a sensitive market dependent on seasons, unequally divided between the Black Sea and well-known for its resorts and 
the mass tourism during the summer period - Constanţa (RO), Dobrich (BG) - and the unexploited rest of the territory.

Given the local conditions, the sustainable tourism seems to be the sector that best combines the economic potential and the logic of protection to produce the sustainable benefits for the local communities. Moreover, the preservation of the cultural and natural heritage is the key for the management of the seasonal tourism, whose only possibility is often limited by the seaside area in the summer period. Indeed, the seasonality is a major problem for the tourism industry and for its economic impact on the territory, because the instability of the revenues from tourism discourage the involvement in the tourism development and the direct assumption of responsibility by the local people in the tourism sectors or the indirect one through the tourists' expenses.

One solution would be the absorption of European funds dedicated to save the coast area of Romania, in amount of over EUR 234 million, which allow the start of works to stop the marine erosion at the level of the entire seaside.

Moreover, the organisation of a pluridisciplinary research program is imposed, so as to reach the protection of all the environment factors (water, air, soil, biodiversity), as a condition of the optimal revaluation of the tourist potential of the Romanian seaside.

\section{References}

[1] Breţcan, P., Complexul lacustru Razim - Sinoe. Editura Transversal, Târgovişte, 2007.

[2] Dogar, A., De ce riscăm să ne pierdem plajele în 20 de ani. Evenimentul Zilei, vineri, 20 august, 2010.

[3] Rădulescu, C. C., Prezent şi perspective de optimizarea valorificării turistice a zonei litorale. Revista Geograful, Anul II (2010), Nr.4, p.39, Bucureşti.

[4] Gâştescu P., Şelariu, O., La morphodinamyque actuelle du littoral roumain de la Mer Noire. Revue roumain de géographie, Tome 38 (1994), p.75, Editura Academiei Române.

[5] Gâştescu, P., Lucrări pentru protecţia plajelor naturale şi realizarea plajelor artificiale. Geografia României, vol.V, 2005, p. 798, Editura Academiei Române, Bucureşti.

[6] Gâştescu, P., Caracteristici hidrologice ale spaţiului maritim costier. In Geografia României, vol.V (2005), p. 820, Editura Academiei Române, Bucureşti.

[7] Gâştescu, P., Zăvoianu, I., Driga, B., Ciupitu, D., Drăgoi, I. J. : Marea Neagră şi litoralul românesc, în România, spaţiu, societate, mediu, p.122, Editura. Academiei Române, 2005, Bucureşti.

[8] Loghin, V., Murătoreanu, G. : Observing and mapping the coastline relief in the Romanian sector of the Black Sea using satellite images. Global Developments in Environmental Earth Observation from Space, Proceedings of the 25th Annual Symposium of the European Association of Remote Sensing Laboratories (EARSeL), Porto, Portugal, June 6-11, 2005.

[9] Mazilu, M., Turism și dezvoltare durabilă. Editura Universitaria,Craiova,,pp.39, 2012.

[10] Mazilu, M., The Romanian Tourism - A Promoter of Globalization and Sustainable Development Factor, Published by WSEAS Press, 2012, pp.237.

[11] Pascariu, G., Potenţialul socio-economic al litoralului românesc. In Geografia României, vol.V, p.839, Editura Academiei Române, București,2005.

[12] Posea, Gr., Grigore, M., Posea, A., Caracteristici morfologice ale litoralului românesc al Mării Negre.,In Geografia României, vol.V, p.796, Editura Academiei Române, Bucureşti, 2005.

[13] Ujvari, I., Marea Neagră. In Geografia apelor României, p.159, Editura Ştiinţifică, Bucureşti,1972.

[14] Information on Agenţia japoneză pentru cooperare internaţională (JICA), Ministerul Mediului şi gospodării apelor, România, 2006, Studiul privind protecţia şi reabilitarea litoralului sudic al României la Marea Neagră, Corporaţia Ecoh

[15] Warren, S., Marron, F., "Stare buna" - obiective de mediu si metodologie pentru elaborarea unui program de masuri. In Implementarea noii directive cadru a apei in bazine pilot (WAFDIP), TR - 7, pag. 1:32, EuropeAid/114902/D/SV/EO, 2005;

[16] Information on Black Sea Red Data Book, http://www.grid.unep.ch/bsein/red book. 